\title{
ACANTHOChILA SPINACOSTA VAN DUZEe, A NEW TINGITID FOR PUERTO RICO
}

Nine species of lacewing bugs or tingitids have been reported from Puerto Rico by Wolcott. ${ }^{1}$ The writer had the opportunity of finding a new tingitid for the Island while making a survey for leafhoppers and fulgorids. ${ }^{2}$

During the month of November 1947, and while collecting leafhoppers at the Aguirre Central Gulf Club, a peculiar yellowing on the foliage of a "corcho prieto" tree, Torrubia fragans (Dum.-Cours) Standley was observed. Upon close examination a mass infestation of lacewing bugs was noticed. Millions of adults and nymphal stages of all sizes and ages were feeding on the undersides of the leaves. Insect material was collected at that time. On March 26, 1952, at the Polytechnic Institute at San Germán, while collecting white-flies and accompanied by Louise Russell, another tree of this same species was found similarly infested by these tingitids. The last infestation of these insects was observed on a large "corcho prieto" tree at Barrio Calero of Aguadilla, on May 13, 1954. The specimens were sent to the U. S. National Museum for identification. R. I. Salier determined them as: Acanthochila spinacosta Van Duzee.

A. spinacosta was deseribed by Van Duzec ${ }^{3}$ in 1907, from a specimen collected at Mandeville, Jamaica, on April 3, 1906, without record of host plant. Drake and Bruner ${ }^{4}$ listed this species from San Pedro de Macorís Dominican Republic. Another related species, Acanthochila sigillata Drake and Bruner, is recorded ${ }^{4}$ from Cuba on Pisonia aculeala. To date the writer

\footnotetext{
${ }^{1}$ Wolcott, G. N., The insects of Puerto Rico, J. Agr. Univ. P.R. $321-4 \& 206-9$, 1948.

2 Caldwell, John S., \& Martorell, L. F., Review of the Auchenorynchous homoptera of Puerto Rico, J. Agr. Univ. P. R. 34 1-2 \& 1-269, 1950.

${ }^{3}$ Van Duzee, E. P., Bul. Buffalo Soc. Nat. Sci. 8 (8) 20, 1907.

${ }^{4}$ Drake, Carl J., \& Bruner, Stephen C., Concerning some tingitidae occurring in the West Indies (Hemip.) Memorias de la Sociedad Cubana de Historia Natural "Felipe Poey", 6 (3-4) 144-54, 1923-24, Habana, Cuba.
} 


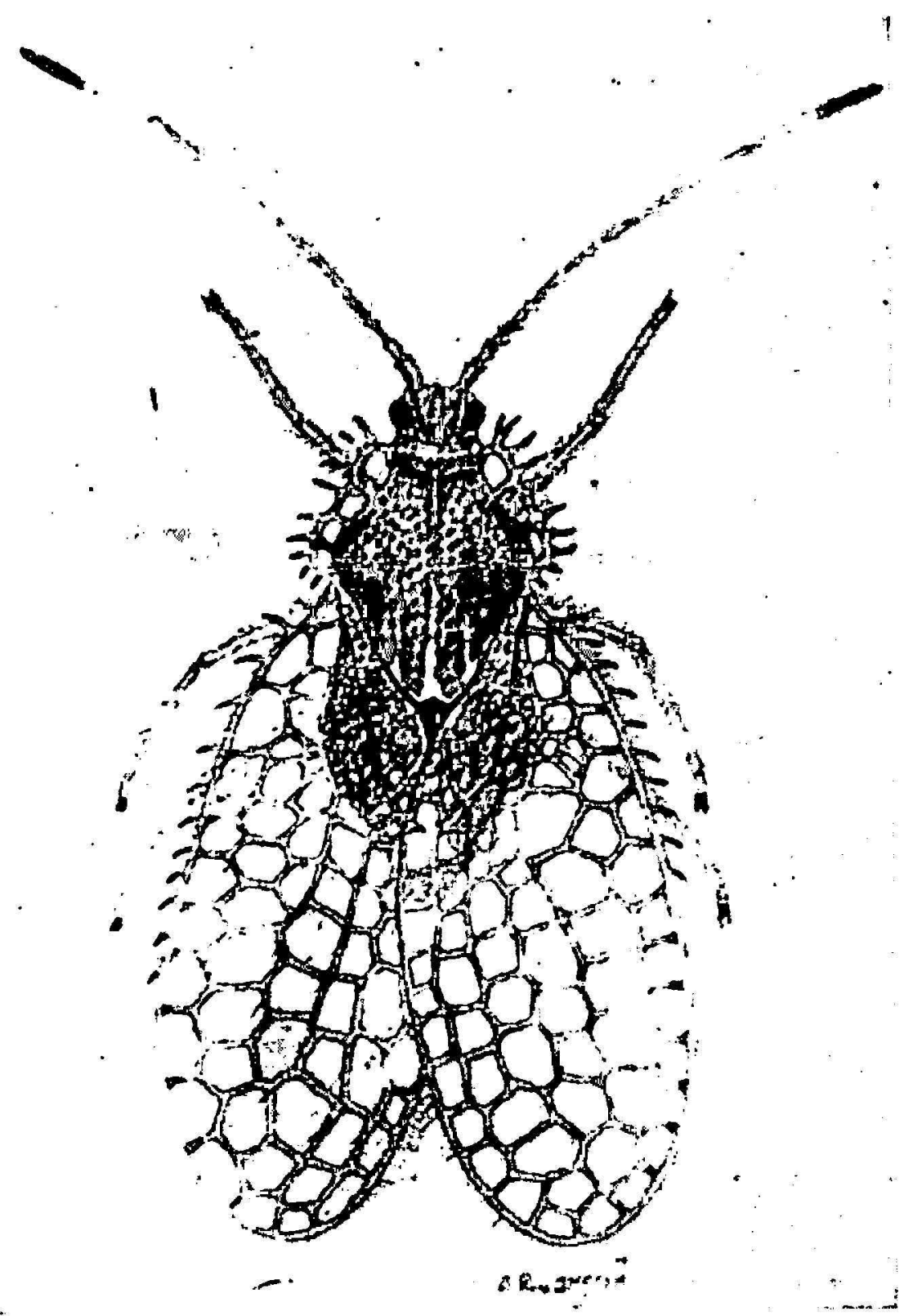

Fig. 1.-The adult lacewing bug, Acanthochila spinacosta Van Duzee (after Drake and Bruner).

has not observed any speries of tingitids on this tree in Puerto Rico, although it occurs quite abundantly at lower elevations on the Island.

Torrubia fragans (Dum.-Cours) Standley, the host tree of Acanthochila spinacosia Van Duzee, commonly known as "corcho prieto", "corcho" "majagua," "majagua quemona", "majagua quemadora", "palo de corcho," and "black mampoo," is found in forests, thickets, and hillsides at lower and middle elevations in Puerto Rico. The tree is also recorded from Icacos, Culebras, St. Thomas, St. Croix, Virgen Gorda, Cuba, Hispaniola, Jamaica, Central and South America. T. fragans was formerly known as Pisonia fragans Dum.-Cours., $P$. obtusata Sw., and $P$. inermis Griseb. 